\title{
PENGARUH HUMAN RELATION, MOTIVASI DAN LINGKUNGAN KERJA TERHADAP PRESTASI KERJA KARYAWAN PADA PT. PRATAMA AGRO SAWIT (PAS) DI BATIN XXIV KABUPATEN BATANG
}

\author{
Etty Siswati, Evi Fauzani \\ STIE Graha Karya Muara Bulian, Jambi, Indonesia
}

\begin{abstract}
The aim of this study. To find out the effect of human relations, motivation and work environment on employee performance at PT. Pratama Agro Sawit (PAS) in Batin XXIV Kabupeten Batanghari. The method of collecting data is used survey method used to obtain information from respondents by using interview techniques and distributing questionnaires and using Likert scale measurements. the sample in this study were employees at PT. Pratama Agro Sawit (PAS) in Batin XXIV Kabupaten Batanghari. The analytical tool used is a multiple linear regression method using computer assistance through the SPSS 20.0 for Windows program. From the calculation of SPSS 20.0 obtained variable human relations tcount of 3.517 , due to tcount $>$ from $t$ table, (3.517> 1.66571, meaning that the independent variable has an influence on the dependent variable, which means there is a partial influence between human relations variables on employee performance at PT . Pratama Agro Sawit in Batin XXIV Kabupaten Batanghari. Motivation variables are 6.515, due to $t$ count> from $t$ table, (6.515> 1.66571), meaning that the independent variable has an influence on the dependent variable, which means there is a partial influence between motivation and achievement employee work at PT. Pratama Agro Sawit (PAS) in Batin XXIV Kabupaten Batanghari. Variable work environment is 0.971. Due to t count <from $t$ table, $(0.971<1.66571)$ means that the independent variable has no influence on the dependent variable, which means there is no influence partial between work environment and work performance ryawan at PT. Pratama Agro Sawit (PAS) in Batin XXIV Kabupaten Batanghari. Simultaneous test (F Test), it can be concluded that the variable human relations, motivation and work environment shows a significant influence on employee performance at PT. Pratama Agro Sawit (PAS) in Batin XXIV, which is proven by the value of $F$ count 35,821 of greater than $F$ table $d f n-k-1$ then $78-3-1=74(F$ table $=2.73$ or $(35,821>2,73)$ The summary model of PT Pratama Agro Sawit (PAS) in Batin XXIV above can be seen that the Adjusted $R$ Square value is 0.668 , so it can be concluded that the percentage influences human relations $\left(X_{1}\right)$, motivation $\left(X_{2}\right)$, and work environment variables $\left(X_{3}\right)$ the variable employee performance at PT Pratama Agro Sawit (PAS) is 0.668 or $66.8 \%$ and the remaining 0.332 or $33.2 \%$ is influenced by other variables not examined in this study.
\end{abstract}

Keywords: Human relations, Motivation and work environment, employee work pretensions

\section{PENDAHULUAN}

Sumber daya manusia merupakan salah satu faktor penting dan memiliki peranan yang besar dalam suatu perusahaan, Salah satu strategi yang dapat ditempuh dalam membentuk sumber daya manusia (SDM) yaitu dengan meciptakan kerjasama antara manusia satu dengan yang lainnya. dengan kata lain faktor human relation (hubungan antar manusia) juga mengambil bagian pada keadaan ini, karena human relation sering dianggap sebagai media komunikasi antar pribadi yang manusiawi dimana telah memasuki tahap psikologis yang saling memahami pikiran, perasaan dan melakukan tindakan bersama.
Menurut Onong

(2009:50) mengungkapkan human relation merupakan komunikasi persuasif yang dilakukan oleh seseorang kepada orang lain secara tatap muka. dalam situasi kerja dan dalam organisasi dengan tujuan untuk meningkatkan semangat dalam bekerja dan bekerjasama agar dapat mencapai hasil yang memuaskan.

Untuk mewujudkan tujuan perusahaan perlu dukungan penuh dari seluruh pihak dalam perusahaan baik manajer atau pemimpin maupun bawahan atau karyawan. Dengan demikian perusahaan harus mampu menciptakan suasana yang kondusif, dimana pimpinan 
harus mampu bekerjasama dengan bawahannya dengan mengarahkan, mengawasi bawahannya serta meyakinkan bahwa ini adalah tujuan bersama yang harus dicapai.

Dalam kegiatan human relation tidak terlepas dari keberadaan pimpinan dalam memberikan motivasi kepada karyawan untuk meningkatkan prestasi kerja karyawan. Oleh karena itu perusahaan harus terus memperhatikan kebutuhan karyawannya, karena karyawan merupakan aset penting bagi sebuah perusahaan.

Menurut Effendy (2009:52) Motivasi adalah kegiatan yang memberikan dorongan kepada seseorang atau diri sendiri untuk mengambil suatu tindakan yang dikehendaki. Jadi, bagaimana memotivasi karyawan untuk bekerja lebih giat, lebih semangat berdasarkan kepada kebutuhan mereka secara memuaskan, baik kebutuhan akan upah, puas hati, demi kemajuan diri dari karyawan itu.

Selain itu dalam menjalankan kegiatannya perusahaan juga harus memperhatikan faktor-faktor yang ada di dalam perusahaan dan di luar perusahaan atau yang disebut dengan lingkungan sekitar. Lingkungan sekitar persahaan yang ada sering disebut kondisi fisik lingkungan kerja.

Menurut Gomes (2008:25) lingkungan kerja adalah proses kerja dimana lingkungan saling berinteraksi menurut pola tertentu, dan masing-masing memiliki karakteristik atau nilai-nilai tertentu mengenai organisasi yang tidak akan lepas daripada lingkungan dimana organisasi itu berada, dan manusianya yang merupakan sentrum segalanya.

Kondisi lingkungan kerja yang menyenangkan terlebih lagi bagi semasa jam kerja akan memperbaiki moral karyawan dan kesungguhan kerja, peralatan yang baik, ruangan kerja yang nyaman, perlindungan terhadap bahaya, ventilasi yang baik, karyawan yang cukup, dan keberhasilan bukan saja dapat menigkatkan prestasi kerja karyawan.
Prestasi kerja karyawan suatu perusahaan dipengaruhi oleh banyak faktor, antara lain Hubungan antar manusia, motivasi dan lingkungan kerja. Karyawan dapat melaksanakan tugasnya secara optimal, karena ditentukan oleh hubungan antara manusia yaitu berupa motivasi atau dorongan untuk bekerja dengan tekun, selain itu juga lingkungan kerja yang nyaman dan mendukung prestasi kerja karyawan.

Menurut Danang Sunyoto (2012:18) prestasi kerja adalah suatu hasil kerja yang dicapai seseorang dalam melaksanakan dan menyelesaikan pekerjaan yang dibebankan kepadanya. Selain itu Mangkunegara (2010: 67) menyatakan bahwa Prestasi kerja adalah hasil kerja secara kualitas yang dicapai oleh seseorang dalam melaksanakan tugasnya sesuai dengan tanggung jawab yang diberikan kepadanya.

\section{METODE PENELITIAN \\ Lokasi dan Objek Penelitian}

Penelitian ini dilakukan dengan mengambil lokasi penelitian di PT. Pratama Agro Sawit (PAS) di Batin XXIV Kabupaten Batanghari. Dalam penelitian ini yang menjadi objek penelitian adalah karyawan pada PT. Pratama Agro Sawit (PAS) di Batin XXIV Kabupaten Batanghari.

Lokasi penelitian ini dipilih karena ditemukan masalah-masalah yang berhubungan dengan human relation, motivasi dan lingkungan kerja pada PT. Pratama Agro Sawit (PAS) di Batin XXIV Kabupaten Batanghari

Jenis penelitian yang digunakan dalam penelitian ini adalah bersifat deskritif kuatitatif.

\section{Alat Analisis Data}

1. Uji Validitas

2. Uji Reliabilitas.

\section{Uji Asumsi Klasik}

Model regresi berganda yang digunakan dalam pengujian hipotesis dikatakan model yang baik apabila model 
tersebut memenuhi normalitas data dan terbebas dari asumsi-asumsi klasik, yaitu normalitas, multikolinearitas, autokorelasi dan heteroskedastisitas (Sujianto, 2009). Dalam penelitian ini, asumsi klasik autokorelasi tidak diuji dengan alasan data yang dikumpulkan dan diolah merupakan data cross section, sedangkan masalah autokorelasi sering terjadi pada data time series. Dengan demikian uji asumsi klasik yang digunakan meliputi uji normalitas, uji multikolinearitas dan uji heteroskedastisitas.

\section{Uji Normalitas}

Uji normalitas bertujuan untuk menguji apakah dalam model regresi, variabel terikat (dependen) dan variabel bebas (independen) memiliki distribusi normal. Model regresi yang baik adalah jika distribusi data normal atau mendekati normal (Ghozali, 2006). Untuk menguji apakah data terdistribusi normal atau tidak dapat dilakukan dengan analisis grafik dan uji statistik. Analisis grafik merupakan cara yang mudah untuk mendeteksi normalitas yaitu dengan melihat penyebaran data (titik) pada sumbu diagonal dari grafik normal probability plot. Pengambilan keputusan dalam uji normalitas menggunakan analisis grafik ini didasarkan pada:

1. Jika data menyebar di sekitar garis diagonal dan mengikuti garis diagonal, maka model regresi memenuhi asumsi normalitas

2. Jika data menyebar jauh dari garis diagonal dan atau tidak mengikuti arah garis diagonal, maka model regresi tidak memenuhi asumsi normalitas.

Menurut Ghozali (2006), uji normalitas dengan grafik dapat menyesatkan kalau tidak hati-hati secara visual kelihatan normal, padahal secara statistik dapat sebaliknya. Oleh sebab itu dianjurkan disamping uji grafik dilengkapi uji statistik. Uji statistik sederhana yang dapat digunakan untuk menguji normalitas residual adalah uji statistik non-parametrik Kolmogorov-Smirnov (K-S).

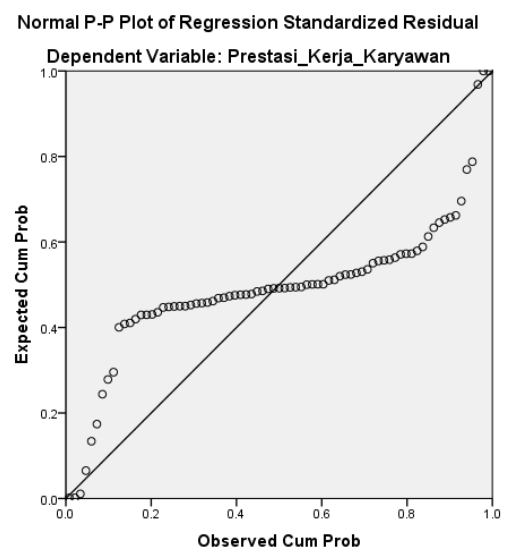

Gambar 1. P.Plot Normalitas

\section{Uji Multikolinieritas}

Uji multikolinieritas bertujuan untuk menguji apakah model regresi ditemukan adanya korelasi antar variabel bebas (independen). Model regresi yang baik seharusnya tidak terjadi korelasi di antara variabel bebas. Jika variabel bebas saling berkorelasi, maka variabel-variabel tersebut tidak ortogonal. Variabel ortogonal adalah variabel bebas yang nilai korelasi antar sesama variabel independen sama dengan nol (Ghozali, 2006). Pengujian ada atau tidaknya multikolinieritas di dalam model regresi dapat dilakukan dengan melihat nilai tolerance dan nilai variance inflation factor (VIF) . Kedua ukuran ini menunjukkan setiap variabel independen manakah yang dijelaskan oleh variabel independen lainnya. Nilai cutoff yang umum dipakai untuk menunjukkan adanya multikolinieritas adalah nilai tolerance $\leq$ 0,10 atau nilai $\mathrm{VIF} \geq 10$ (Ghozali,2006). 
Tabel 1. Nilai Tolerance dan VIF

Coefficients $^{\mathrm{a}}$

\begin{tabular}{|c|c|c|c|c|c|c|c|}
\hline \multirow[t]{2}{*}{ Model } & \multicolumn{2}{|c|}{ Unstandardized Coefficients } & \multirow{2}{*}{$\begin{array}{l}\text { Standardized } \\
\text { Coefficients } \\
\text { Beta }\end{array}$} & \multirow[t]{2}{*}{$\mathrm{t}$} & \multirow[t]{2}{*}{ Sig. } & \multicolumn{2}{|c|}{ Collinearity Statistics } \\
\hline & B & Std. Error & & & & Tolerance & VIF \\
\hline $\begin{array}{l}\text { (Constant) } \\
\text { Human_Realtion } \\
\text { Motivasi } \\
\text { Lingungan_Kerja }\end{array}$ & $\begin{array}{l}-755204.973 \\
.306 \\
.594 \\
.081\end{array}$ & $\begin{array}{l}1016042.951 \\
.087 \\
.091 \\
.084\end{array}$ & $\begin{array}{l}.333 \\
.581 \\
.070\end{array}$ & $\begin{array}{l}-.743 \\
3.517 \\
6.515 \\
.971\end{array}$ & $\begin{array}{l}.460 \\
.001 \\
.000 \\
.335\end{array}$ & $\begin{array}{l}.486 \\
.550 \\
.848\end{array}$ & $\begin{array}{l}2.057 \\
1.818 \\
1.180\end{array}$ \\
\hline
\end{tabular}

a. Dependent Variable: Prestasi_Kerja_Karyawan

\section{Uji Heteroskedastisitas}

Uji heteroskedastisitas bertujuan untuk menguji apakah dalam model regresi terjadi ketidaksamaan variance dari residual satu pengamatan ke pengamatan yang lain (Ghozali,2006). Jika variance dari residual satu pengamatan ke pengamatan yang lain tetap, maka disebut homoskedastisitas dan jika berbeda disebut heteroskedastisitas. Model regresi yang baik adalah yang homoskedastisitas atau tidak terjadi heterokdastisitas. Untuk mendeteksi ada atau tidaknya heteroskedastisitas dapat dilakukan dengan melihat grafik Plot antara nilai prediksi variabel terikat (dependen) dengan nilai residualnya. Dasar analisis grafik Plot adalah sebagai berikut:

1. Jika ada pola tertentu, seperti titik-titik yang ada membentuk pola tertentu yang teratur maka mengindikasikan telah terjadi heteroskedastisitas

2. Jika tidak ada pola yang jelas, serta titiktitik menyebar di atas dan di bawah angka 0 pada sumbu $\mathrm{Y}$, maka tidak terjadi heteroskedastisitas (Ghozali, 2006).

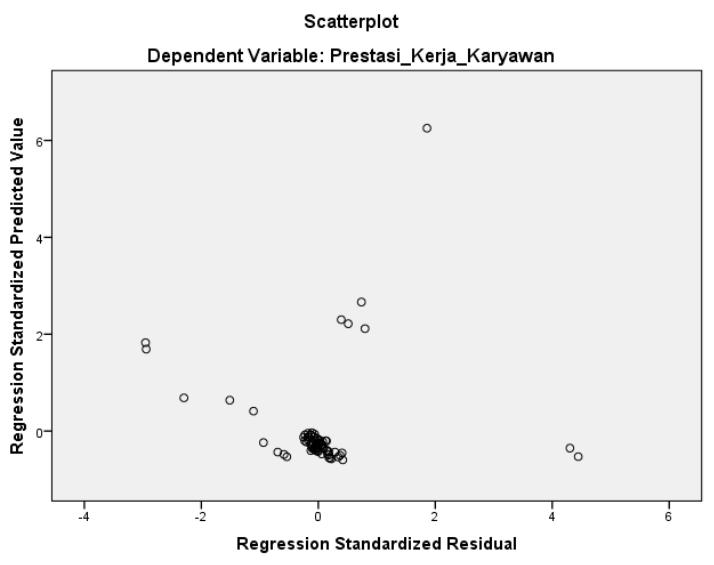

Gambar 2. Heteroskedastisitas

\section{Uji Autokorelasi}

Uji Autokorelasi adalah untuk menguji apakah dalam persamaan regresi ditemukan adanya korelasi antara kesalahan penggangu pada periode $t$ dengan kesalahan pengganggu periode t-I. Dalam penelitian ini dugunakan uji DurbinWatson dengan dasar pengambilan keputusan sebagai berikut :

Tabel 2. Pengambilan Keputusan

\begin{tabular}{cc}
\hline Tingkat Autokorelasi & Jenis Autokorelasi \\
\hline$<1.503$ & Ada Autokorelasi positif \\
$1.503-1.696$ & Tanpa kesimpulan \\
$1.696-2.304$ & Tidak ada Autokorelasi \\
$1.696-2497$ & Tampa kesimpulan \\
$>2.497$ & Ada Autokorelasi \\
\hline
\end{tabular}

Sumber : Suliyanto,2011

Hasil uji Autokorelasi dengan Durbin Watson sebagai berikut :

Tabel 3. Hasil Uji Autokorelasi

Model Summary ${ }^{b}$

\begin{tabular}{|l|c|c|c|c|c|}
\hline Model & R & R Square & Adjusted R Square & Std. Error of the Estimate & Durbin-Watson \\
\hline 1 & $.825^{\mathrm{a}}$ & .681 & .668 & 1501852.70787 & 1.959 \\
\hline
\end{tabular}

a. Predictors: (Constant), Lingungan_Kerja, Motivasi, Human_Realtion

b. Dependent Variable: Prestasi_Kerja_Karyawan 
Berdasarkan hasil olah regresi diketahui bahwa nilai Durbin-Watson sebesar 1.959 yang berada diantara 1.696 samapi 2.304 yaitu berada pada daerah tidak ada autokorelasi, sehinga disimpulkan model regresi ini tidak ada autokorelasi.

\section{HASIL DAN PEMBAHASAN}

Analisis Regresi Linear Berganda

Menurut Rachman Rijono (2015:70), Analisis regresi berganda merupakan alat analisis yang digunakan untuk mengetahui pengaruh antara $\mathrm{X}_{1}$ (Human Relation), $\mathrm{X}_{2}$ (Motivasi) dan $\mathrm{X}_{3}$ (Lingkungan Kerja) Terhadap Y (Prestasi Kerja Karyawan). Untuk mendapatkan gambaran yang jelas tentang pengaruh variable yang ada maka digunakan alat analisis data. Dalam penelitian ini alat analisis yang digunakan adalah dengan menggunakan Regresi Linear Berganda, Dimana analisis ini digunakan untuk mengetahui pengaruh dari variabel bebas terhadap variabel terikat.

Table 4. Hasil Regresi Liner Berganda

Coefficients $^{\mathrm{a}}$

\begin{tabular}{|c|c|c|c|c|c|c|c|}
\hline \multirow[t]{2}{*}{ Model } & \multicolumn{2}{|c|}{ Unstandardized Coefficients } & \multirow{2}{*}{$\begin{array}{r}\text { Standardized } \\
\text { Coefficients } \\
\text { Beta }\end{array}$} & \multirow[b]{2}{*}{$\mathrm{t}$} & \multirow[b]{2}{*}{ Sig. } & \multicolumn{2}{|c|}{ Collinearity Statistics } \\
\hline & B & Std. Error & & & & Tolerance & VIF \\
\hline \multirow{4}{*}{$\begin{array}{l}\text { Motivasi } \\
\text { Lingungan_Kerja }\end{array}$} & -755204.973 & 1016042.951 & & -.743 & .460 & & \\
\hline & .306 & .087 & .333 & 3.517 & .001 & .486 & 2.057 \\
\hline & .594 & .091 & .581 & 6.515 & .000 & .550 & 1.818 \\
\hline & .081 & .084 & .070 & .971 & .335 & .848 & 1.180 \\
\hline
\end{tabular}

a. Dependent Variable: Prestasi_Kerja_Karyawan

Hasil perhitungan regersi linier berganda dengan program SPSS versi 20 dari tabel koefisien, di peroleh pesamaan sebagai berikut :

$$
\mathrm{Y}=-755204.973+0,306 \mathrm{X}_{1}+0,594
$$

$\mathrm{X}_{2}+0,081 \mathrm{X}_{3}$

Dari persamaan diatas dapat diiartikan sebagai berikut :

1. $\mathrm{a}=-755204.973$

Artinya apabila variabel Human Relation , Motivasi, dan Lingkungan kerja bernilai nomaka Prestasi Kerja adalah sebesar -755204.973

2. $X_{1}=$ Human Relation $=0,306$

Nilai koefisien untuk human relation naik sebesar 0,306 dan bertanda positif ini menjukan bahwa setiap kenaikan satu satuan maka variabel Prestasi kerja akan naik sebesar 0,306 dengan asumsi variabel lain tetap.

3. $\mathrm{X}_{2}=$ Motivasi

Nilai koefisien untuk motivasi $\left(\mathrm{X}_{2}\right)$ sebesar 0,594 dan bertanda positif , ini menujukan bahwa setiap kenaikan satu satuan maka variabel Pretasi kerja akan naik sebesar 0,594 dengan asumsi variabel lain tetap.

4. $\mathrm{X}_{3}=$ Lingkungan Kerja

Nilai koefisien untuk lingungan kerja sebesar 0,081 dan bertanda positif ini menujukan bahwa setiap kenaikan satu satuan maka variabel Prestasi kerja akan naik sebesar 0,081 dengan asumsi variabel lain tetap

\section{Hasil Pengujian Hipotesis Uji Parsial (Uji t)}

Dalam penelitian ini juga menggunakan bantuan SPSS versi 20.0 yang mana hasil uji $\mathrm{t}$ juga dapat dilihat pada tabel diatas (Coefficients).

\section{Pengaruh Human relation terhadap prestasi kerja karyawan pada Pratama Agro Sawit (PAS) di Batin XXIV Kabupaten Batanghari}

Variabel human relation dari pengujian diatas didapatlah nilai 3,517>1,66571. Dimana $t$ hitung lebih besar dari tabel maka Ho diterima. Jadi kesimpulannya adalah variabel human relation berpengaruh signifikan terhadap variabel 
prestasi kerja karyawan pada PT. Pratama Agro Sawit (PAS) di Batin XXIV Kabupaten Batanghari.

2. Pengaruh motivasi terhadap prestasi kerja karyawan pada PT. Pratama Agro Sawit (PAS) di Batin XXIV Kabupaten Batanghari

Variabel motivasi dari pengujian diatas didapatlah nilai $6.515>1,66571$. Dimana thitung lebih besar dari tabel maka Ho diterima. Jadi kesimpulannya adalah variabel motivasi berpengaruh signifikan terhadap variabel prestasi kerja karyawan pada PT. Pratama Agro Sawit (PAS) di Batin XXIV Kabupaten Batanghari.

3. Pengaruh lingkungan kerja terhadap prestasi kerja karyawan pada Pratama Agro Sawit (PAS) di Batin XXIV Kabupeten Batanghari

Variabel lingkunan kerja dari pengujian diatas didapatlah nilai $0,971<1,66571$.
Dimana $\mathrm{t}$ hitung lebih kecil dari $\mathrm{t}$ tabel . Jadi kesimpulannya adalah variabel lingkungan kerja tidak berpengaruh signifikan terhadap variabel prestasi kerja karyawan pada PT. Pratama Agro Sawit (PAS) di Batin XXIV. Kabupaten Batanghari

4. Pengaruh Human relation, motivasi, lingkungaan kerja terhadap prestasi kerja karyawan pada Pratama Agro Sawit (PAS) di Batin XXIV Kabupaaten Batanghari

\section{Uji Simultan (Uji F)}

Uji statistik $F$ dilakukan untuk menguji apakah terdapat pengaruh yang signifikan variabel human relation, motivasi, lingkungan kerja sebagai variabel indipenden terhadap prestasi kerja variabel devenden. Hasil proses uji $\mathrm{F}$ dengan nilai signifikansi > 0,05 ditunjukan pada tabel :

Tabel. 5 Uji F

ANOVA $^{\mathrm{a}}$

\begin{tabular}{|ll|c|r|c|c|c|}
\hline Model & & Sum of Squares & df & Mean Square & F & Sig. \\
\hline \multirow{2}{*}{1} & Regression & 351877997708691.600 & 3 & 117292665902897.200 & 52.002 & $.000^{\mathrm{b}}$ \\
& Residual & 164655993597374.750 & 73 & 2255561556128.421 & & \\
& Total & 516533991306066.400 & 76 & & & \\
\hline
\end{tabular}

a. Dependent Variable: Prestasi_Kerja_Karyawan

b. Predictors: (Constant), Lingungan_Kerja, Motivasi, Human_Realtion

Dari tabel diatas uji simultan (Uji F) maka dapat disimpulkan bahwa variabel human relation, motivasi dan lingkungan kerja menunjukkan adanya pengaruh yang signifikan terhadap prestasi kerja karyawan pada PT. Pratama Agro Sawit (PAS) di Batin XXIV, yang dibuktikan dengan nilai $F$ hitung 35,821 dari lebih besar dari $F$ tabel 2,73 atau $(35,821>2,73)$.

\section{Koefisien Determinasi}

Uji koefisien determinasi ini bertujuan untuk mengetahui seberapa besar presentase variabel human relation (X1), motivasi $\left(\mathrm{X}_{2}\right)$ dan lingkungan kerja (X3) terhadap variabel prestasi kerja karyawan (Y) untuk melihat nilai koefisien determinasi dapat dilihat pada tabel dibawah ini :

Table 6. Koefisien Determination

Model Summary ${ }^{b}$

\begin{tabular}{|l|c|c|c|l|c|}
\hline Model & $\mathrm{R}$ & R Square & Adjusted R Square & Std. Error of the Estimate & Durbin-Watson \\
\hline 1 & $.825^{\mathrm{a}}$ & .681 & .668 & 1501852.70787 & 1.959 \\
\hline
\end{tabular}

a. Predictors: (Constant), Lingungan_Kerja, Motivasi, Human_Realtion

b. Dependent Variable: Prestasi_Kerja_Karyawan 
Dari tabel model summary $\mathrm{V}$ diatas dapat dilihat bahwa nilai Adjusted $\mathrm{R}$ Square sebesar 0,668. Jadi dapat disimpulkan bahwa presentase pengaruh variabel human relation (X1), motivasi (X2), dan lingkungan kerja (X3) terhadap variabel prestasi kerja karyawan pada PT. Pratama Agro Sawit (PAS) sebesar 0,668 atau sebesar $66,8 \%$ dan sisanya 0,332 atau $33,2 \%$ dipengaruhi oleh variabel lain yang tidak diteliti dalam penelitian ini.

\section{SIMPULAN}

Berdasarkan hasil penelitian dan pembahasan, maka beberapa pokok kesimpulan pokok penelitian dapat dijelaskan sebagai berikut :

1. Variabel human relation didapatlah 3,517 > 1,66571. Dimana thitung lebih besar dari ttabel maka Ho diterima. Jadi kesimpulannya adalah variabel human relation berpengaruh signifikan terhadap variabel prestasi kerja karyawan pada PT. Pratama Agro Sawit (PAS) di Batin XXIV.Kabupaten Batanghari

2. Variabel motivasi didapatlah $6.515>$ 1,66571. Dimana thitung lebih besar dari $\mathrm{t}$ tabel maka Ho diterima. Jadi kesimpulannya adalah variabel motivasi berpengaruh signifikan terhadap variabel prestasi kerja karyawan pada PT. PT. Pratama Agro Sawit (PAS) di Batin XXIV.Kabupaten Batanghari

3. Variabel lingkungan kerja didapatlah $0,971<1,66571$. Dimana $t$ hitung lebih kecil dari t tabel. Jadi kesimpulannya adalah variabel lingkungan kerja tidak berpengaruh signifikan terhadap variabel prestasi kerja karyawan pada PT. Pratama Agro Sawit (PAS) di Batin XXIV.Kabupaten Batanghari

4. Uji simultan (Uji F) maka dapat disimpulkan bahwa variabel human relation, motivasi dan lingkungan kerja menunjukkan adanya pengaruh yang signifikan terhadap prestasi kerja karyawan pada PT. Pratama Agro Sawit (PAS) di Batin XXIV Kabupaten Batanghari, yang dibuktikan dengan nilai $\mathrm{F}$ hitung 35,821 dari lebih besar dari $F$ tabel 2,73 atau $(35,821>2,73)$.

Koefisien Determinasi Tabel model summary PT. Pratama Agro Sawit (PAS) di Batin XXIV Kabupaten Batanghari diatas dapat dilihat bahwa nilai Adjusted $\mathrm{R}$ Square sebesar 0,668. Jadi dapat disimpulkan bahwa presentase pengaruh variabel human relation (X1), motivasi (X2), dan lingkungan kerja (X3) terhadap variabel prestasi kerja karyawan pada PT. Pratama Agro Sawit (PAS) sebesar 0,668 atau sebesar $66,8 \%$ dan sisanya 0,332 atau $33,2 \%$ dipengaruhi oleh variabel lain yang tidak diteliti dalam penelitian ini.

\section{DAFTAR PUSTAKA}

Cardoso Gomes, Faustino. 2008. Manajemen Sumber Daya Manusia. edisi pertama. cetakan keempat. Jakarta : Andi Offset.

Effendy, Uchana Onong.2009. Ilmu Komunikasi Teori dan Praktek. Bandung : PT Remaja Rosdakarya.

Hasibuan, Malayu S. P. 2008. Manajemen Sumber Daya Manusia. Jakarta: PT. Bumi Aksara

Husnan, Suad dan Enny Pudjiastuti. 2010. Dasar-Dasar Manajemen. Edisi Kelima. Yogyakarta : UPP STIM YKPN

Ghozali, Imam. 2006. "Aplikasi Analisis Multivariate dengan Program SPSS “. Semarang : UNDIP.

Mangkunegara, Anwar Prabu. 2010. Manajemen Sumber Daya Manusia Perusahaan. Bandung : Remaja Rosdakarya.

Mathis, R.L. \& J.H. Jackson. 2006. Human Resource Management: Manajemen Sumber Daya Manusia. Terjemahan Dian Angelia. Jakarta: Salemba Empat

Nuraini, T. 2013. Manajemen Sumber Daya Manusia. Yayasan Aini Syam: Pekanbaru.

Oei, Istijanto. 2010. Riset Sumber Daya Manusia. Jakarta: PT. Gramedia Pustaka Utama. 
Veithzal, Rivai. 2011. Manajemen Sumber Daya Manusia Untuk Perusahaan Dari Teori Ke Praktek. Jakarta : pt. Rajagrafindo persada.

Sedarmayanti. 2009. Sumber Daya Manusia dan Produktivitas Kerja. Bandung: CV Mandar Maju..2014. Sumber Daya Manusia dan Produktivitas Kerja. Jakarta: Mandar Maju.

Sadili, Samsudin. 2009. Manajemen Sumber Daya Manusia. Bandung : Pustaka Setia.

Siagian, Sondang. 2008. Manajemen Sumber Daya Manusia. Jakarta: Bumi Aksara.

Sugiyono. 2011. Metode Penelitian Kuantitaif Kualitatif dan $\mathrm{R} \& \mathrm{~B}$, Bandung: Alfabeta

Sugiono, Danang. 2009. Statistika Untuk Penelitian. Cetakan Keempat belas. Bandung: Alvabeta.

Suharsimi, Arikunto.2010. Prosedur Penelitian : Suatu Pendekatan Praktek. Jakarta : Rineka Cipta

Sunyoto, Agus. 2008. Manajemen Sumber Daya Manusia. Jakarta : Badan Penerbit IPWI.

Sunyoto, D. 2012. Manajemen Sumber Daya Manusia. Yogyakarta : CAPS

Sunyoto, Danang. 2013. Teori, Kuesioner, dan Analisis Data Sumber Daya Manusia dalam Organisasi. Yogyakarta: Multi Presindo.

Sutrisno, Edy. 2010. Manajemen Sumber Daya Manusia. Jakarta: Kencana 